http://dx.doi.org/10.7833/116-2-1330

\title{
IS IT NOT GOD'S MERCY THAT NOURISHES AND SUSTAINS US ... FOREVER? \\ SOME THEOLOGICAL PERSPECTIVES ON ENTANGLED SUSTAINABILITIES
}

\author{
Ernst M. Conradie \\ University of the Western Cape
}

\begin{abstract}
This essay explores the question whether and if so what contribution Christian systematic theology can make to contemporary discourse on sustainability and more specifically 'entangled sustainabilities'. It acknowledges that any such contribution would be deeply contested. It nevertheless suggests that one such contribution can lie in a critique of the underlying assumptions of discourse on sustainability and specifically any claims for ultimacy regarding whether, how and what it is that is supposed to be sustained. This critique is complemented by a constructive response on the basis of three classic aspects of faith in God's providence. Accordingly, it is God's mercy and therefore God's justice that nourishes and sustains us. This cannot be taken for granted though, as it depends upon a reading of the signs of the time, in rapidly changing circumstances. Any hope to find something that could endure and be sustained forever may well be heretical.
\end{abstract}

Key Words: Christianity; Concursus; Conservatio; Gubernatio; Limits; Providence; Sustainability; Systematic Theology; Ultimate

\section{What Contribution Can Come from Christian Theology?}

What can Christian theology in general and systematic theology in particular contribute to contemporary discourse on sustainability? ${ }^{1}$ Those familiar with early discourse on sustainability may take the answer to this question for granted. A working committee of the World Council of Churches on Church and Society, dealing with matters of faith and science in a changing world, already used the term sustainability at a meeting in Bucharest in 1974. At the Nairobi Assembly of the World Council of Churches in 1975 the phrase "Towards a Just, Participatory and Sustainable Society" was introduced to describe the social agenda of the church. Ever since that time concerns over sustainability have been on ecumenical agendas.

However, the legitimacy of the question will also be contested, for several reasons. Firstly, any discussion of sustainability necessarily requires multi-disciplinary collaboration so that any claims for particularity would seem to undermine a spirit of collaboration. Secondly, the role of religion and theology in such multi-disciplinary collaboration is not at all very clear, especially since the debate is dominated by the fields of economics and development studies. The assumption is that any approach that focuses on beliefs and worldviews may alienate moral reasoning from science-based problem solving. ${ }^{2}$ Thirdly, where the role of religion is considered, this is dealt with in functionalist terms, namely to recognise the moral sources embedded in religious traditions (e.g. as expressed in the Earth Charter) and the often crucial role played by Faith Based Organisations in social transformation at the local level. Again, multi-faith collaboration is valued here more than 
any notion of religious particularity. Fourthly, if any contribution is to be expected from Christian theology, this would probably come from Ethics or Practical Theology, not from Systematic Theology. Finally, on intra-theological grounds, at least in the reformed tradition, the well-being of the planet is more important than the well-being of Christianity, even where the latter is considered as a necessary requirement for the former. ${ }^{3}$ The primary theological question is therefore not what Christian theology can contribute but what would enhance sustainability.

Nevertheless, there is a dual danger in refraining from raising the question. As Steve de Gruchy observed (in a discussion of the absence of references to religion in the Sustainable Livelihoods Framework), "How can we expect to understand and help people if we miss the very thing that they consider to be the most important thing in their lives simply because it is not important in our lives?"4 On the one hand such withdrawal from even raising the question may lead to what Wolfgang Huber describes as self-secularisation, treating Christianity merely in terms of its ethical significance or its power to sustain social cohesion without reference to its substantive vision that underlie such values, virtues and a sense of responsibility. ${ }^{5}$ On the other hand, this may fail to recognise the distinct contribution that Christian systematic theology may be able to make to (secular) discourse on sustainability. If Christians merely reiterate what others are saying but do not make the kind of contribution that only they can make, this would amount to a failure of responsibility. This begs the question whether systematic theologians do have anything to contribute in this regard. I suspect that this question may be raised with considerable suspicions, also amongst Christian theologians from other sub-disciplines, not to mention from within other religious traditions or in a secular environment.

In this contribution I will offer some perspectives on this question. I suggest that a fivefold answer would be appropriate. Firstly, the mere presence and participation of theologians in discourse on sustainability, even if this presence is characterised by a dignified silence, is already a significant contribution since it demonstrates some solidarity.

Secondly, the role of Christian theology cannot be to dominate the debate, to take over the roles of chairperson, secretary or even treasurer. Given the wealth of literature produced on sustainability from a very wide variety of disciplines, epitomised by the ten volumes of the Berkshire Encyclopedia of Sustainability, ${ }^{6}$ this is hardly feasible in any case. Instead, one role could be to help ensure that marginalised voices are heard at the table of secular discourse on sustainability. Instead of speaking for their own interests, theologians may need to insist that other voices be heard. This role would scarcely be possible if Christianity is represented by an elderly, male ecclesial elite, irrespective of geographic context or race. Here the catholicity of the church is vital - the remarkable ability of the Christian gospel to take root in such diverse geographic cultural contexts and bioregions.

Thirdly, Christian theology does bring a long-standing tradition of reflection on such issues to the table. This comes with a toolkit of vocabulary (on a sustainable society, on sustainable communities and sustainable livelihoods - see below) and a historic memory that should not be underestimated.

I would suggest that such contributions are primary, but also to some extent obvious enough that it does not need further elaboration. Instead I will focus on two other contributions, namely the ability to help critique some of the underlying assumptions of secular discourse on sustainability and some constructive positions. 


\section{A Critique of the Underlying Assumptions of Discourse on Sustainability}

The Socratic method of critiquing the assumptions, often taken for granted in discourse in the public sphere, is as necessary as it is usually unwelcome. This task is best addressed by philosophers, but philosophy as the mother of the sciences has never been a well-demarcated discipline. Christian theology may well be regarded, at least from the outside, as a particular kind of philosophy, one that is based on specific texts and traditions and focusing on a particular set of questions about ultimate origins, ultimate purposes and the ultimate significance of ordinary life, together with questions about the deepest diagnosis of the malaise of the human condition and proposed remedies for that. ${ }^{7}$ In short, Christian systematic theologians may not take the lead here but may help to raise some uncomfortable questions, prompted by the sensitivities that are particular to this discipline. Let me unpack this in more detail.

It may help to suggest that the term sustainability describes a process in the same way that education and development describe processes rather than goals. To study sustainability is to study a characteristic of a process and that requires multi-disciplinary collaboration since such a process is inherently multi-dimensional. What kind of process is this supposed to be then? This is not so easy to answer. In a way the question regarding discourse on sustainability is what the question really is.

At first the question, raised within the context of the original Limits to Growth report $(1972),{ }^{8}$ was whether or not the use of non-renewable resources can be sustained, given human population growth (although the term sustainability did not appear in this report yet) and increasing consumption of fossil fuels. This is of course a non-sensical question since the use of non-renewable resources can by definition not be sustained. The more appropriate question therefore seems to be how long the use of such resources (including for all practical purposes coal and oil) can be sustained (an important question for policy making). This raises questions around efficiency and unnecessary waste. A related question for engineers is of a technological nature: how can the use of such resources be extended and optimised? Can suitable replacements (e.g. in terms of energy sources) be found or produced?

The focus partially shifted away from such questions with the Brundtland report entitled Our Common Future (1987), namely in order to address the sustainable use of renewable resources such as water, fisheries, forests and especially soil. In its famous definition, sustainability was understood as the use of resources to attend to current needs without compromising the ability of future generations to attend to their own needs. ${ }^{9}$ The main concerns here are over the pollution of such resources but also over the ability of ecosystems to replenish themselves, for example regarding the fertility of the soil. The question is therefore whether current patterns of production and consumption are compatible with the carrying capacity of land, measured by ecological footprint and in terms of biomass. Since biomass can be stored (e.g. in trees or fossil fuels), it is possible to utilise more biomass for human consumption than is produced in a given year.

Another shift, especially since the Rio Earth Summit (1992) was related to concerns over the human victims of ecological contamination and degradation, raising issues over environmental justice and environmental racism. This link between social justice and environmental sustainability was pre-empted by the World Council of Church at both its Nairobi (1975) and Vancouver (1983) assemblies. One may say that the (rather utilitarian) question is whether the benefits of economic production and consumption for some outweigh the costs for others and whether this pattern can be continued without such social instability that the viability of economic systems is undermined. In the Western Cape this 
may be captured in terms of access to sanitation (flush toilets) amidst chronic water shortages.

An even more significant shift took place with the annual meetings of the Conference of the Parties in the context of the UN Convention Framework on Climate Change, namely to focus on the absorption capacity of the biosphere. Sustainability is here defined in terms of the ability of the biosphere to absorb the waste products of an industrialised economy, most notably carbon dioxide, but also toxic waste and especially nuclear waste. Everything can be recycled but this requires time so that the production of waste (i.e. a high concentration of particular chemicals) can exceed the biosphere's absorption capacity. This capacity is determined by the rules of chemistry (and not economics!). In the case of greenhouse gases the absorption takes place through photosynthesis, the oceans and the atmosphere, leading to flourishing plant life but also to the acidification of the oceans and to global warming. The question thus becomes: how long can excessive waste be produced without jeopardising the system as a whole?

A final shift may be associated with the $15^{\text {th }}$ Conference of the Parties in Copenhagen (2009) when it became abundantly clear that economic and political changes will also require social transformation, that is, changes in the hearts and minds, and especially the cultural patterns of the world's so-called consumer class. ${ }^{10}$ Patterns of production and policy changes require political will and that is dependent upon voter support. This begged questions about theories and mechanisms for social change. ${ }^{11}$ It also prompted questions around what it is that is worth sustaining, i.e. what institutions and forms of culture are important enough to maintain even though they may contribute to excessive waste (e.g. a high carbon footprint). One may raise questions of this nature regarding tourism, automobiles, telecommunication systems, mega-sports events, universities, swimming pools, suburban gardens, etc. Each of these can be maintained if less waste is produced somewhere else in the system so that the system as a whole can still absorb such waste. For that, some sacrifices have to be made somewhere. At an individual level this is easily understood, namely to allocate more financial resources for a birthday party than for a normal family meal - as long as the total costs remain within the family's annual budget. We readily save some funds for the special occasion. The problem here is that the costs of a large carbon footprint have to be carried unwillingly by those who have not been part of the decision making processes, including non-human animals. Since the carbon footprint of some (countries) is excessive and since this pattern is being (carbon) copied for the sake of 'development', there seems to be a widespread global unwillingness to stay within a carbon budget that would be sustainable, i.e. one where carbon emissions can be fully absorbed through photosynthesis alone (and not through the atmosphere or the oceans). Instead, it is estimated that only $17 \%$ of carbon emissions are captured through land sinks. ${ }^{12}$

The distortions, inequalities and injustices that are tolerated in socio-economic systems can be maintained for a while but if these are exacerbated this will inevitably cause social instability and unrest - as is abundantly clear in South Africa. In this way economic inequality must be regarded as a major threat for sustainability. ${ }^{13}$ This is paradoxical: although sustainability may be regarded in minimalist terms as a norm for prudence ("do not undermine survival"), it offers a comprehensive critique of the global economy. And, "In the debate over what societies should sustain and why, we are forced to reflect on what sustains humanity and why." 14 It is not the environment that is unsustainable; it is businessas-usual that cannot be sustained by the biophysical environment. ${ }^{15}$

Given this last shift, the question what is it that is supposed to be sustained have prompted renewed forms of ideology critique. Some would say that discourse on 
sustainability has become itself suspect because the question is raised merely in order to legitimise consumerist behaviour - or something like middle class morality, white monopoly capitalism, North Atlantic hegemony, Eurogance, industrialised capitalism, or Western civilisation. In other words, questions around sustainability are raised in contexts dominated by those who hope to sustain what cannot be sustained.

A different set of questions arises in relation to the way in which the term 'sustainable' is used as an adjective to qualify something else. If so, sustainability is not an aim in itself but a qualifier to suggest a range of options within a given spectrum with a given set of assumptions. This is especially the case when the term sustainability is used in conjunction with economic growth or social development. Economic growth can be sustainable if and only if this is not correlated with biophysical throughput. This will require a process of dematerialisation in economic production and the use of renewable forms of energy. ${ }^{16}$ Since this is hardly the case, with a sustained increase in biophysical throughput and global carbon emissions (at least until 2015), ${ }^{17}$ sustainable growth must practically be regarded as a contradiction in terms. ${ }^{18}$

The situation is more complex with the notion of sustainable development, first promoted by the Brundtlandt-report, mainstreamed at the World Summit on Sustainable Development (Johannesburg, 2002) and widely endorsed through the United Nation's formulation of Sustainable Development Goals (2015). ${ }^{19}$ This has implied that sustainability has become the new 'master signifier'. The notion of sustainable development also captures the underlying vision of the ANC Government's National Development Plan (2012). However, insofar as socio-economic development requires economic growth, the same reservations apply.

In addition, there are of course diverging paradigms of what development entails so that it scarcely helps to add yet another qualifier to development discourse. This is aggravated by endless debates on appropriate distinctions between 'developed' and 'developing' countries, over-developed and under-developed economies, ${ }^{20}$ the global North and the global South, economic centres and economic peripheries. ${ }^{21}$ Given its track record and despite huge investments in finance, staff and infrastructure, the 'failure of development' (to perpetuate instead of overcome inequalities and hierarchies) cannot be rectified by making that failure more sustainable! $!^{22}$ The underlying problem is that the still dominant paradigm of development is not sustainable since it is premised on Western notions of progress and linear ideas of history. ${ }^{23}$ As I have argued elsewhere, the time has come to raise the question why the term 'development' cannot be dropped altogether. ${ }^{24}$ Perhaps a moratorium on using the term would be appropriate or else the project of development may need to be abandoned as quasi-colonial. The alternative is to discern different paradigms in development discourse ${ }^{25}$ or to qualify the term development (e.g. as social development, human-centred development, sustainable development, etc.). However, the failure of globalised discourse on sustainable development to achieve social justice prompted ecumenical reservations over the very notion of sustainability because the term was deemed as a euphemism for greening late-industrial neo-liberal capitalism. It was beginning to sustain the wrong sort of world. ${ }^{26}$ Instead, the emphasis shifted towards ecological integrity.

There are by now several suggestions where the qualifier 'sustainable' is retained but tied to alternative concepts. Thus there is discussion on the notion of a sustainable society, sustainable communities, ${ }^{27}$ sustainable communion, ${ }^{28}$ and sustainable livelihoods. ${ }^{29}$ The notion of sustainable livelihoods is best understood not merely as yet another paradigm within development discourse but as an alternative umbrella concept. This means that development may be regarded as an aspect of livelihoods and not vice versa. In each case 
there is distinct set of assumptions that govern such discourse. The result of such discussions is that sustainability cannot be regarded as an end in itself so that the focus again shifts to what it is that is supposed to be sustained.

Yet another set of questions are prompted by the very notion of sustainability. Is this the most appropriate qualifier? What does it actually mean? The etymology of the word may help: it is derived from the Latin sus-tenere (to hold), i.e. to hold up, to carry the weight, to keep something from falling or sinking, to carry on, to support, to allow something to continue for a period of time. The supporting role of the biophysical environment may be unproblematic except where this is explained in anthropocentric terms as if the earth is there merely to support, i.e. to provide resources for human activities.

Further questions emerge over the assumed time-frame. Usually, the emphasis in discourse on sustainability is on a longer term vision, stretching over hundreds of years (e.g. regarding fossil fuels, climate change) or even thousands of years (e.g. regarding radioactive waste). However, if scenarios over the very long term are taken into account, this also begs questions around evolutionary change. Similar questions may be raised over cultural evolution. Why is it all that important to keep things going? Is change not equally important? This is not merely a matter of social transformation, moving towards a society that has never been. It is also about adaptability, the flexibility to confront random fluctuations, for example in weather patterns. Stability may seem to be a typical characteristic of ecosystems (as Aldo Leopold famous maxim suggests ${ }^{30}$ ), but adaptability is even more important over the long term, while rigidity is the road to extinction. Such adaptability has been crucial in early human evolution. Humans did not adapt to any one ecosystem on which they remained dependent, but developed coping mechanisms to deal with climate fluctuations in any one location, to move to and adapt to radically different climates ${ }^{31}$ and to adapt their environments to address their needs through niche construction. ${ }^{32}$ Such adaptability always involves risk-taking but in evolutionary terms such risks are necessary for survival. This emphasis on adaptability is of course rather risky since it conjures up prospects for geo-engineering to confront climate change, ${ }^{33}$ but it does raise disturbing questions about the suitability of the term sustainability.

For theologians such questions should be hardly surprising given a certain sensitivity for ultimate concepts. Philosophers and social critics alike have the task to confront "systematically distorted communication" (Habermas), to expose hidden ideologies, to undermine what is taken for granted in a given culture. For Christians, this is a matter of prophetic critique, of reading the signs of the time, to diagnose the deepest roots of a predicament beneath its many surface-level manifestations (i.e. the task of Christian sintalk ${ }^{34}$ ), to expose forms of idolatry, and to proclaim an alternative vision for the good society (e.g. with reference to God's coming reign).

Moreover, theologians have a special sensitivity, perhaps more so than their colleagues in comparative religion, to recognise wherever concepts are attributed a penultimate or even an ultimate status. This applies to our most trusted concepts, such as democracy, education, equality, freedom, health, human dignity, justice, life, peace, survival, truth, well-being and so forth. The legitimacy of these concepts is often taken for granted, even where their meaning is contested philosophically. However, once one asks, for example, why humans have dignity and how that relates to the dignity of other animals, such dignity becomes elusive, a shifting cypher that assumes its own intrinsic value. Often such concepts carry religious or quasi-religious significance. This applies even more to what one may call 'guiding concepts' for social transformation. ${ }^{35}$ These are concepts that express penultimate visions for the future, with constructive mixed with destructive consequences. They guide 
entire fields of study. Examples include apartheid (!), colonial conquest, development, liberation, reconciliation, reconstruction, and so forth. The problem here is that sustainability can easily become a secularised notion of eternity. This comes complete with an own soteriology insofar as sustainability (or sustainable development) conjures up faith in human progress and the ability to save ourselves. As Willis Jenkins observes,

Debating models and meaning of sustainability distracts attention from its quasi-religious function as a paradoxical salvation story that supports the extension of human power over the earth in order to rescue the earth from human powers. By accreting and absorbing matters of a religious depth, the idea of sustainability may thus work to subjugate religion and ethics to imperatives of power. ... Considered as a 'secularised eternity', a salvation concept for humans who imagine the survival of their own power as the most significant thing in the cosmos, the idea of sustainability begins to corrode rather than cultivate moral capacities. ${ }^{36}$

Theologians cannot avoid using such terms and become equally entangled in conceptual confusion. However, they have one advantage that is inherent to their own discipline, namely the need to relate such concepts to what is regarded as truly ultimate, namely God. ${ }^{37}$ One may immediately want to add that ultimate reality is socially constructed too and that there are many notions of what is ultimate (God, the Supreme Being, etc). However, even if God-talk is nothing more than a social construction (which I am not suggesting), its scope should not be domesticated prematurely: it speaks about nothing less than the ultimate. There may be many constructions of what is ultimate, and a pantheon of (lesser?) divinities, but (as I argued elsewhere) what is ultimate by definition has to be in the singular, or else it is not ultimate. ${ }^{38}$ This is not to claim any legitimacy for Christian God-talk, only to recognise a certain sensitivity for situations where concepts such as sustainability become all-encompassing and therefore amorphous and in the end emptied of meaning.

The prophetic critique of any quasi-ultimate status attributed to concepts such as sustainability necessarily prompts a recognition of the situatedness of any use of the concept within particular constellations of power. A theo-logical critique of sustainability would resist such ultimate status since that would amount to a theological legitimation of concepts other than God as ultimate. Instead, it would recognise the legitimacy embedded in the notion of "entangled sustainabilities" as an "analytical instrument to investigate context-dependent, i.e. situated notions, discourses, and practices of sustainability and their global and local entanglements". ${ }^{39}$ Discourse on sustainability is at best a form of situated knowledge. Moreover, the Augustinian notion of non posse non peccare would suggest that such entanglement also involves radical distortions that can be ameliorated but cannot be overcome from within. We are caught in a mess from which we can no longer escape, to which we each contribute albeit not equally so, and under which we all suffer, but again not equally so. $^{40}$

\section{Sustainability and Discourse on God's Providence}

One may submit that Christian systematic theology offers critical (and often not very systematic) reflection on the ways in which Christians talk about the triune God's identity and character, but then on the basis of what is retrospectively confessed to be God's work. This also requires a constructive responsibility, namely to articulate ever anew what is indeed held to be of ultimate significance, to tell the story of what God has done, is doing and will be doing. This is always done from within a particular social location and in conversation with many insiders and outsiders. In the context of discourse on sustainability, I suggest that this would traditionally require reflection on stories about God's work of 
providence, i.e. God's caring for God's own beloved creation, also providing in our human needs. This is arguably at least one appropriate locus for theological reflection on climate change and on sustainability. This is also to invite contestation over the theodicy problem: Does God really care, can God make a difference, why is God apparently absent and does God even 'exist' (Hans Küng)? This is no trivial question, as acute theological reflection from Pacific islands such as Kiribas and Tivalu indicates: Do rising sea levels mean that God's covenant with Noah no longer holds? ${ }^{41}$ Is providence required or perhaps redemption? Can God rescue us from climate change? Who are included in this "for us and our salvation"? What is God really up to? The secular response to such intractable questions may well be to insist that religion and theology be excluded from any further collaborative dialogue on sustainability!

Theological reflection on God's providence is deeply contested also for reasons that are embedded in the very notion of providence. By itself providence requires foresight (from the Latin pro-videre), the crucial ability to anticipate future developments and the consequences of current policies and actions. Together with knowledge and insight, this is a necessary requirement for wisdom. However, once providence is extended towards God, this begs interminable questions around God's so-called omniscience, divine determinism and free will. These problems may merely be noted here. They certainly apply to theological discourse on sustainability as well, but are not particular to this theme.

A more complex set of problems emerge when the meaning of God's providence is unpacked beyond the virtue of caring for one's loved ones, including children, the elderly, pets, domestic animals and the land itself. Traditionally, at least in the reformed tradition, the meaning of providence may be captured in a threefold distinction between conservatio, gubernatio and concursus. Often though, especially in discourse on theology and the natural sciences, matters related to providence are subsumed under or collapsed into a generalised discussion of creatio continua or of "divine action in the world". The traditional threefold distinction may nevertheless help to circumscribe the nature of the underlying problems related to sustainability.

a) In the Dutch neo-Calvinism of Abraham Kuyper and Herman Bavinck God's work of conservation is explicitly related to the fall of humanity. ${ }^{42}$ This is no generalised (or for that matter Anglicanised) notion of conservation or preservation but a form of "general grace" based on a deliberate response from God not to relinquish the work of 'his' hands (or the fruits of her womb?), to protect the world against the destructive impact of (structural) evil and to create some necessary space for the long story of God's work of salvation through Israel, the ministry of Jesus of Nazareth and the work of God's Spirit in and through the church. In short, the world is sustained, from one moment to the next, by God's mercy. Things are thus kept from falling apart (Chinua Achebe). This is bitterly ironic because the way in which God supposedly does that is through the socalled orders of creation, including marriage, the family and the state. In apartheid theology such orders included ethnicity so that the orders were deemed necessary to keep people apart on the basis of race and ethnicity. 'Conservation' was indeed conservative but operated far beyond the doctrine of providence by offering, in fact, a quasi-soteriology. ${ }^{43}$

For others the so-called "laws of nature" (rather than the orders of creation) would suffice to explain how such order is maintained - albeit that it then becomes less necessary for a deistic God to attend to the process beyond the very beginning. For Calvin, who knew nothing yet of gravity, it is God's providence that keeps the earth from falling - since he realised that the earth was round but could not gather how soil, 
which is heavier than air, could possibly float in the air. ${ }^{44}$ It is therefore far from clear how such a notion of conservatio could contribute to contemporary discourse on sustainability, in a world that does not seem to require such a hypothesis (Pierre-Simon Laplace). At the same time, the very term sustainability suggests an equally uncertain need for a secular notion of providence. We then have to place our hope in the regenerative power of Mother Nature or simply in the absorption and recycling capacity of ecosystems - that are stretched to their 'limits'. Otherwise it is us who have to save the earth in order to save ourselves. But can we put our trust in such human capacities? Indeed, (God's) providence may well be a 'myth' without which we cannot live.

b) The Christian confession of trust in the triune God is in a God of history, who steers and guides history towards the consummation of God's work. The end of this is not predetermined but the whole of history is situated within the framework of God's blessings and God's promises - and the fulfilment of such promises. Amidst many false prophets and ongoing attempts to seek theological justification for particular social causes there is a clear need for an encompassing vision of God's work and for more detailed discernment in particular circumstances, ${ }^{45}$ to read the signs of the time through social analysis (seeing), to discern where God is within all of this (judging) and to seek God's will (acting). Who would dare to identify the "finger of God" in human history or even in wider evolutionary history? This task is fraught with many dangers - as the histories of Germany ${ }^{46}$ and South Africa ${ }^{47}$ amply illustrate. Critics would rightly point to the dangers of a theological legitimation of particular interests, to construct God according to one's needs and desires. Yet, for Christians there is only one thing which is more dangerous than trying to identify the finger of God in human history - and that is not to even raise the question.

This has a secular counterpart in discourse on sustainability too. The question is not whether or not some notion of gubernatio may be entertained but which one. It is hard to predict scenarios for the shape of human societies beyond one hundred years, at least if the past one hundred years is anything to go by. It is also dangerous to make pronouncements over the "end of history" or to offer apocalyptic self-fulfilling prophecies. Likewise, technological utopias, dreams of longevity, hopes for artificial intelligence and fears over trans-human mutations are as unreliable as they may be inevitable. Yet it would be grossly irresponsible not to even raise questions around sustainability, to wonder where things are really going, to be concerned over a changing climate, the rapid loss of biodiversity, soil fertility, nuclear waste or the acidification of the oceans. Secular notions of gubernatio allow for a full range of positions between continuity (sustainability) and radical discontinuity (apocalyptic doom or utopia). By contrast, one may observe that the Hebrew and Christian vocabulary that governs discourse on gubernatio speaks of promise and fulfilment, blessing and vocation, law and gospel, truth ('emeth) and loyalty (hesed), mercy (rachum $\approx$ womb) and justice (tsedakah), covenant and renewed covenant, cross and resurrection, incarnation and recapitulation. It is richly textured and inherently dynamic, both starkly realistic and ethically attractive.

c) The Christian trust in God's providence implies neither fatalism nor quietism. It does not abrogate human responsibilities. I cannot merely rely on God to put food on the table or to have a safe journey. I may need to work hard to earn a salary, purchase the food and prepare it myself. I need to ensure that there is fuel in the tank, that the vehicle is in a good condition and that I abide by traffic regulations. Nevertheless, faith in 
God's providence is a way of acknowledging retrospectively that the fact that I have food on the table is ultimately not my own doing, neither is a safe journey. It depends on many other variables beyond my locus of control. Sceptics may appreciate such a sense of humility but may softly suggest that there is no need for divine involvement here. This does indicate a highly complex set of questions around divine action in the world $^{48}$ and human and divine interaction (concursus). In philosophic categories this is the paradox of double agency. Austin Farrer maintained that this paradox, and the implied problem of the causal joint, is irresolvable. ${ }^{49}$ Others have suggested that agency is multi-dimensional so that one may identify different levels of agency that are not necessarily mutually exclusive. If there are many contributing factors to any act, one may need to identify these, but the pertinent task is to discern the necessary and then the decisive factors that are involved. In this way it is quite possible to regard individual, communal, organisational, cultural and divine levels of action as compatible with each other. $^{50}$

This paradox also applies to discourse on sustainability. I have the responsibility to act in such a way that this leaves options for the future, while whatever I do is also done by the society in which I am situated, but whether or not patterns of production and consumption will be sustainable lies beyond my (or your) locus of control. Again, the vocabulary of concursus may help to express an inherent uncertainty and to discern where the problem lies.

This discussion of God's providence may yield a constructive sense of purpose for Christian communities. However, it also serves a critical function to test the ultimate value of ethical imperatives. As Willis Jenkins rightly observes, "By situating the relation of human and ecological systems within a broader economy of God, theological ideas can raise metaethical questions around background assumptions of how we think we are sustained. ... It may be theology, ironically, that can keep sustainability from functioning as an empty salvation concept by opening it to the deep moral questions it involves."51 This is not to offer ready-made theological answers to complex questions but to critique the shallowness of some Christian and also some secular responses precisely by engaging with such questions rigorously.

\section{What is that would Abide Forever?}

The time in which we live may be characterised by two contrasting movements. On the one hand there is a postmodern recognition of the Heraclitian flux - that may be understood as a necessary response to the modernist logic of universal rationality, mastery and control. On the other hand discourse on sustainability suggests a different response to the same logic of domination, namely one where the need for some continuity amidst the flux is recognised. Theologians have not been too helpful here as fundamentalists have proclaimed eternal doctrinal truths while liberals have found some or other equally generalised category (religious experience, ultimate concern, ethics, development, liberation, social cohesion, or social transformation) that may stem the tide of the Heraclitian flux and guard against new forms of domination.

My sense is that systematic theologians in the wake of the Enlightenment should not be looking to doctrinal truths (or to ethical principles, natural laws or glorious goals) to find something that would last forever, despite and especially given concerns over sustainability. What, then, is it that may be sustained and how is it to be sustained? Nothing may last forever, but perhaps some things may abide for while? 
In the biblical roots of Christianity there is not much that remains stable that is not subject to at times radical historical transitions. This dynamism surely has to do with the promises of God to an enslaved people, promises that open up an unexpected future, previously deemed impossible. There is an ongoing need to read the signs of the times and to discern what God is up to. This does not imply that nothing abides. The recurring theme of Psalm 136 is that God's loyalty (hesed) endures 'forever' (olam). This is precisely not a category that can be taken for granted or captured in any formula - as is illustrated in the various verses of the Psalm, in changing circumstances, amidst contestation, always open to conjecture. This is no abstract Greek notion of eternity but a Jewish sense of what lies beyond the horizon in space and time. ${ }^{52}$ Elsewhere in the Psalms such loyalty is closely tied to God's mercy but this cannot be taken for granted either and must be called upon ever anew, typically in times of distress (Ps 25:6, 31:9, 40:11, 123:3, etc). One may therefore say that sustainability is arguably a function of justice and of mercy (and these together) and that, for the psalmist, the key lies with the identity and character of the God of Israel. ${ }^{53}$

In John 15 there is talk of abiding and this is explained in terms of love: "As the Father loved me, so I have loved you; abide in my love" (John 15:9, NRSV). There is nothing sentimental about this love as the cross (laying down one's life for one's friends, verse 13) and the subsequent history of persecution (verse 20) illustrates. Again what is abiding is not governed by eternal truths but by a dynamic trust in God, conscious of the coming hour $(16: 2)$. God's mercy is not merely a matter of providence but also of salvation and indeed consummation. Not even the church will abide for ever. Yet, as Willis Jenkins observes, that may be where the most important contribution of Christian communities regarding sustainability lies, namely "in sustaining the capacity of future generations to forgive us"! 54

This suggests that secular discourse on sustainability may be in need of a richer tapestry of concepts that describe the underlying conditions for fertility and flourishing, for what Holmes Rolston calls the "projective thrust" of ecosystems. ${ }^{55}$ Again, the lyrics of the Psalmist provide a sense of direction for what nourishes and sustains us:

10 Steadfast love (hesed) and faithfulness ('emeth) will meet righteousness (or justice tsedakah) and peace (shalom) will kiss each other.

11 Faithfulness ('emeth) will spring up from the ground, and righteousness (tsedakah) will look down from the sky.

12 The Lord will give what is good, and our land will yield its increase.

13 Righteousness (tsedakah) will go before him, and will make a path for his steps (Psalm 85:10-13, NRSV).

It is only on the basis of the indicative of God's mercy and justice that sustains us, that the imperative of Christian virtues and practices can be sustained. Here an even richer tapestry of concepts becomes possible: repentance, confession of guilt, complicity and injustice, wisdom, justice, resilience, frugality, hope. While Christians would tend to support secular notions of sustainability on this basis, they would also wish to resist shallow assumptions that locate the sources of sustainability in something other than mercy, justice and knowing God (Micah 6:8). 


\section{BIBLIOGRAPHY}

Bavinck, Herman. “Common Grace.” Calvin Theological Journal 24 (1989):35-65.

Béguin-Austin, Midge, ed. Sustainable Growth - Contradiction in Terms? Geneva: The Ecumenical Institute, 1993.

Bonhoeffer, Dietrich. Ethics. Dietrich Bonhoeffer Works. Vol. 5. Minneapolis: Fortress Press, 2005.

Brümmer, Vincent, "Farrer, Wiles and the Causal Joint." In: Brümmer on Meaning and the Christian Faith, 283-294. Aldershot Ashgate, 2007.

Clingerman, Forrest, and Kevin O'Brein. Theological and Ethical Perspectives on Climate Engineering: Calming the Storm. Lanham: Lexington Books, 2016.

Coetzee, Murray H., and Ernst M. Conradie. "Apartheid as Quasi-Soteriology: The Remaining Lure and Threat." Journal of Theology for Southern Africa 138 (2010):112-23.

Conradie, Ernst M. "A Few Notes on the Heuristic Key of 'Sustainable Community'.' Scriptura 75 (2000):345-57.

Conradie, Ernst M. "Healing in Soterioleogical Perspective." Religion and Theology 13.1 (2006):3-22.

Conradie, Ernst M. Lewend En Kragtig? In Gesprek Oor God Se Handelinge. Wellington: Bible Media, 2010.

Conradie, Ernst M. Creation and Salvation: Dialogue on Abraham Kuyper's Legacy for Contemporary Ecotheology. Leiden: Brill Publishers, 2011.

Conradie, Ernst M. Saving the Earth? The Legacy of Reformed Views on Re-Creation. Berlin: LIT Verlag, 2013.

Conradie, Ernst M. Reconciliation as a Guiding Vision for South Africa? Stellenbosch: SUN Press, 2013.

Conradie, Ernst M. "Twelve Theses on the Place of Christian Theology in MultiDisciplinary Conversations." Stellenbosch Theological Journal 1.1 (2015):375-86.

Conradie, Ernst M. The Earth in God's Economy: Creation, Salvation and Consummation in Ecological Perspective. Studies in Religion and the Environment. Vol. 10. Berlin: LIT Verlag, 2015.

Conradie, Ernst M. "Why Can’t the Term Development Just Be Dropped Altogether? Some Reflections on the Concept of Maturation as Alternative to Development Discourse." HTS Teologiese Studies/Theological Studies 72.4 (2016):1-11.

Conradie, Ernst M. “An Emerging Horizon: Learning to See the World in a Different Light through the Liturgy." The Nature of Things: Rediscovering the Spiritual in God's Creation. Eds. Bruxton, Graham and Norman Habel. Eugene: Pickwick, 2016. 41 57.

Conradie, Ernst M. Redeeming Sin? Social Diagnostics Amidst Ecological Destruction. Lanham: Lexington 2017.

De Gruchy, Steve M. Keeping Body and Soul Together: Reflections by Steve De Gruchy on Theology and Development. Pietermaritzburg: Cluster Publications, 2015.

Development, World Commission on Environment and. Our Common Future. Oxford \& New York, 1987. 
Durand, Jaap. "Die Vinger van God", in Teks binne Konteks: Versamelde Opstelle oor Kerk en Politiek, edited by DJ Smit (Bellville: Universiteit van Wes-Kaapland, 1987):91-99.

Farrer, Austin. Faith and Speculation. London: Adam \& Charles Back, 1967.

Huber, Wolfgang. Kirche in der Zeitenwende: Gesellschaftlicher Wandel und Erneurung Der Kirche. Gütersloh: Bertelsmann Stiftung, 1998.

Jablonka, Eva, and Marion J. Lamb. Evolution in Four Dimensions: Genetic, Epigenetic, Behavioral, and Symbolic Variation in the History of Life. Cambridge: MIT Press, 2014.

Jenkins, Willis. The Spirit of Sustainablility. Berkshire Encyclopedia of Sustainability Volume 1. Great Barrington: Berkshire Publishers, 2009.

Jenkins, Willis. The Future of Ethics: Sustainability, Social Justice, and Religious Creativity. Washington: Georgetown University Press, 2013.

Korten, David. Getting to the 21st Century: Voluntary Action and the Global Agenda. West Hartford: Kumarian Press, 1990.

Leopold, Aldo. A Sand County Almanac. New York: Ballantine, 1949.

Lucas, John R. Freedom and Grace. Grand Rapids: Eerdmans, 1976.

Meadows, Donella H., Dennis L. Meadows, and Jorgen Randers. Beyond the Limits: Confronting Global Collapse, Envisioning a Sustainable Future. Post Mills Chelsea Green, 1992.

Meadows, Donella H., et al. The Limits to Growth: A Report for the Club of Rome's Project on the Predicament of Mankind. New York: Universe Books, 1972.

Nürnberger, Klaus. Prosperity, Poverty \& Pollution. Managing the Approaching Crisis. Pietermaritzburg: Cluster Publications, 1999.

Oberman, Heiko. The Two Reformations: The Journey from the Last Days to the New World. New Haven: Yale University Press, 2003.

Pearson, Clive. Oceaning Readings on Creation and Redemption. Creation and Salvation, Volume 2: A Companion on Recent Theological Movements. Studies in Religion and the Environment. Ed. Conradie, Ernst M. Vol. 6. Berlin: LIT Verlag, 2012.

Potts, Rick. Humanity's Decent: The Consequences of Ecological Instability. New York: Avon Books, 1996.

Rasmussen, Larry L. “The Future Isn't What It Used to Be: 'Limits to Growth' and Christian Ethics.” Lutheran Quarterly 27 (1975):101-11.

Rasmussen, Larry L. Earth Community, Earth Ethics. Maryknoll: Orbis Books, 1996. Print.

Rasmussen, Larry L. Christianity and Sustainable Communites. The Encyclopedia of Religion and Nature. Ed. Taylor, B. London \& New York: Continuum, 2005.

Reichard, Joshua. "Pentecost, Process, and Power: A Critical Comparison of Concursus in Operational Pentecostal-Charismatic Theology and Philosophical Process-Relational Theology." University of the Western Cape., 2010.

Rolston, Holmes (III). Conserving Natural Value. New York Columbia University Press, 1994.

Russell, John, Nancey Murphy, and William R. Stoeger. Scientific Perspectives on Divine Action: Twenty Years of Challenge and Progress. Vatican City: Vatican Observatory Publications, 2008. 
http://scriptura.journals.ac.za

Some Theological Perspectives on Entangled Sustainabilities

Schreiner, Susan E. "Creation and Providence." The Calvin Handbook. Ed. Selderhuis, Herman J. Grand Rapids: WB Eerdmans, 2009.

South African Council of Churches, Climate Change Committee. Climate ChangeA Challenge to the Churches in South Africa. Marshalltown: SACC, 2009.

Starke, Linda (ed) 2004. State of the World 2004. Washington: Worldwatch Institute. State of the World 2004. Washington: Worldwatch Institute, 2004.

Sutcliffe, Bob. "Development after Ecology." The North, the South and the Environment: Ecological Constraints and the Global Economy. Eds. Bhaskar, V. and A Glyn. London: Earthscan Publications, 1995. 32-58.

UNEP. Decoupling Natural Resource Use and Environmental Impacts from Economic Growth. A Report of the Working Group on Decoupling to the International Resource Panel 2011.

Wellman, David J. Sustainable Communities. Geneva: World Council of Churches, 2001.

Wood, Charles M. Vision and Discernment: An Orientation in Theological Study. Atlanta: Scholars Press, 1985.

World Commission on Environment and Development. Our Common Future. Oxford \& New York, 1987.

\section{Endnotes}

1 This contribution is based on a paper delivered at the Kosmos workshop on "Religion, Sustainability and Politics", hosted by the Faculty of Theology, Humboldt University in Berlin, 7-10 June 2017.

2 W. Jenkins, The future of Ethics: Sustainability, Social Justice and Religious creativity (Washington: Georgetown University Press, 2013:169).

3 Ernst M. Conradie. Redeeming Sin? Social Diagnostics Amidst Ecological Destruction (Lanham: Lexington Books, 2017) (forthcoming).

4 Steve. M. De Gruchy, Keeping Body and Soul Together: Reflections by Steve de Gruchy on Theology and Development (Pietermaritzburg: Cluster Publications, 2015:258).

5 Wolfgang. Huber, Kirche in der Zeitenwende: Gesellschaftlicher Wandel und Erneurung der Kirche, (Gütersloh: Bertelsmann Stiftung, 1998).

6 Willis Jenkins, The Spirit of Sustainability: Berkshire Encyclopedia of Sustainability Volume 1, ed. W. Jenkins (Great Barrington: Berkshire Publisher, 2009).

7 Ernst.M. Conradie, "Twelve Theses on the Place of Christian Theology in Multi-disciplinary Conversations" in. Stellenbosch Theological Journal 1.1 (2015):375-386.

8 My analysis below follows a highly perceptive early article by Larry Rasmussen (1975) in which he identifies three limits to growth, namely economic limits (non-renewable resources), biospheric limits (absorption capacity) and social limits (the complexity of inducing social change). One of the earliest uses of the term sustainability may be found in the 1969 International Union for Conservation of Nature document that described its goal as achieving the "the highest sustainable quality of life".

Rasmussen, Larry L. "The Future isn't what it used to be: 'Limits to Growth' and Christian Ethics.” Lutheran Quarterly 27 (1975):101-11.

Jenkins, Willis. The Future of Et; hics: Sustainability, Social Justice, and Religious Creativity. Washington: Georgetown University Press, 2013:135.

Meadows, Donella H., Dennis L. Meadows, and Jorgen Randers. Beyond the Limits: Confronting Global Collapse, Envisioning a Sustainable Future. Post Mills Chelsea Green, 1992.

Meadows, Donella H., et al. The Limits to Growth: A Report for the Club of Rome's Project on the Predicament of Mankind. New York: Universe Books, 1972.

9 This widely cited definition of the World Commission on Environment and Development (the Brundtland report) reads in full: "Sustainable development is development that meets the needs of the present without compromising the ability of future generations to meet their own needs. It contains within it two key concepts: the concept of 'needs', in particular the essential needs of the world's poor, to which overriding priority 
should be given; and the idea of limitations imposed by the state of technology and social organisation on the environment's ability to meet present and future needs." (Our Common Future, Chapter 2, par. 1).

Ecological Constraints and the Global Economy, eds. V. Bhaskar and A. Glyn (Earthscan Publications, London. 1995:32-58).

12 The Global Carbon Project's 2016 report captures this in one of their 'highlights': "Of the total emissions from human activities during the period $2006-2015$, about $56 \%$ accumulated in the atmosphere, $27 \%$ in the ocean and $17 \%$ on land. During this period, the size of the natural sinks has grown in response to the increasing emissions, though year-to-year variability of that growth is large. The 2015 land sink estimate was a significantly low one in the 60 -year record studied." See

http://www.globalcarbonproject.org/carbonbudget/16/highlights.htm (retrieved 20 April 2017).

Jenkins, Willis. The Future of Ethics: Sustainability, Social Justice, and Religious Creativity.

(Washington: Georgetown University Press, 2013:43.45).

South African Council of Churches, Climate Change Committee. Climate Change-A Challenge to the Churches in South Africa. (Marshalltown: SACC, 2009).

14 Willis Jenkins, The future of Ethics: Sustainability, Social Justice and Religious creativity (Washington: Georgetown University Press, 2013:169).

15 Steve M. De Gruchy, Keeping Body and Soul Together: Reflections by Steve de Gruchy on Theology and Development (Pietermaritzburg: Cluster Publications, 2015:51).

16 A UNEP report entitled on Decoupling Natural Resource Use and Environmental Impacts from Economic Growth indicates that, on a worldwide scale, resource consumption is steeply on the rise while resource consumption is still a reliable companion of economic prosperity (2011:ix). Development can only be sustainable if it is without growth in throughput of matter and energy beyond regenerative and absorptive capacities. This would require 'decoupling', i.e. "using less resources per unit of economic output and reducing the environmental impact of any resources that are used or economic activities that are undertaken" (UNEP 2011:xiii). Dematerialisation then entails using less material, energy, water and land resources for the same economic output.

UNEP. Decoupling Natural Resource Use and Environmental Impacts from Economic Growth. A Report of the Working Group on Decoupling to the International Resource Panel (2011).

The Global Carbon Project's most recent annual Global Carbon Budget (released 14 November 2016) indicated that, "Carbon dioxide (CO2) emissions from fossil fuel burning and cement production did not increase in 2015 , with a total of $9.9 \pm 0.5 \mathrm{GtC}$ (36.3 GtCO2) emitted to the atmosphere. Emissions from the past two years were the highest in human history and 60\% higher than in 1990 . In 2015, coal burning was responsible for $41 \%$ of the total emissions, oil $34 \%$, gas $19 \%$, cement $6 \%$, and gas flaring $1 \%$. Emissions are projected to increase by $0.2 \%$ in 2015 with a range of $-1.0 \%$ to $+1.8 \%$." Another 'highlight' reads: "The annual growth rate of atmospheric $\mathrm{CO} 2$ was $6.3 \pm 0.2 \mathrm{GtC}$ in 2015 , corresponding to an increase of $2.97 \pm 0.09$ parts per million in the atmospheric concentration. This growth is well above the 2006-2015 average of $4.5 \pm 0.1 \mathrm{GtC}$ yr-1 and the result of the lower land sink during El Niño. The global atmospheric CO2 concentration reached $399.4 \pm 0.10$ ppm on average over 2015 and have continued to increase in 2016". For this sobering report, see http://www.globalcarbonproject.org/carbonbudget/16/highlights.htm (accessed 20 April 2017).

18 Midge Béguin-Austin, Sustainable Growth - Contradiction in Terms? ed. M. Béguin-Austin (Geneva: The Ecumenical Institute, 1993).

19 The Sustainable Development Goals is a set of 17 global goals with 169 targets contained in paragraph 54 of United Nations Resolution A/RES/70/1 of 25 September 2015. It is officially referred to as "Transforming our World: the 2030 Agenda for Sustainable Development”. It replaced the Millennium Development Goals as an agenda for development after 2015.

20 Steve M. De Gruchy, Keeping Body and Soul Together: Reflections by Steve de Gruchy on Theology and Development (Pietermaritzburg: Cluster Publications, 2015:58).

21 Nürnberger, Klaus. Prosperity, Poverty \& Pollution. Managing the Approaching Crisis. Pietermaritzburg: Cluster Publications, (1999).

22 Steve M. De Gruchy, Keeping Body and Soul Together: Reflections by Steve de Gruchy on Theology and Development (Pietermaritzburg: Cluster Publications, 2015:52).

23 Steve M. De Gruchy, Keeping Body and Soul Together: Reflections by Steve de Gruchy on Theology and Development (Pietermaritzburg: Cluster Publications, 2015:59).

24 Conradie, Ernst M. "Why Can't the Term Development Just Be Dropped Altogether? Some Reflections on the Concept of Maturation as Alternative to Development Discourse." HTS Teologiese Studies/Theological 
Studies 72.4 (2016):1-11

25 David Korten, Getting to the $21^{\text {st }}$ Century: Voluntary Action and the Global Agenda, (West Hartford: Kumarian, 1990)

Steve M. De Gruchy, Keeping Body and Soul Together: Reflections by Steve de Gruchy on Theology and Development (Pietermaritzburg: Cluster Publications, 2015:62).

26 Willis Jenkins, The future of Ethics: Sustainability, Social Justice and Religious creativity (Washington: Georgetown University Press, 2013:137).

27 Larry L. Rasmussen, Earth Community, Earth Ethics, (Maryknoll: Orbis Books, 1996)

David J. Wellman, Sustainable Communities, (Geneva: World Council of Churches, 2001).

28 Ernst. M. Conradie, “A Few Notes on the Heuristic Key of 'Sustainable Community'," Scriptura 7 (2000):345-357).

29 Steve M. De Gruchy, Keeping Body and Soul Together: Reflections by Steve de Gruchy on Theology and Development (Pietermaritzburg: Cluster Publications, 2015:87-104).

30 Aldo Leopold, A Sand County Almanac, (New York: Ballantine, 1949).

31 Rick Potts, Humanity's Descent: The Consequences of Ecological Instability. (New York: Avon Books, 1996).

32 Eva Jablonka Marion J. Lamb, Evolution in Four Dimensions: Genetic, Epigenetic, Behavioral, and Symbolic Variation in the History of Life. (Cambridge: MIT Press, 2014).

33 Forrest Clingerman, Kevin J. O' Brien, Theological and Ethical Perspectives on Climate Engineering: Calming the Storm. (Lanham: Lexington Books, 2016).

34 Ernst M. Conradie. Redeeming Sin? Social Diagnostics Amidst Ecological Destruction (Lanham: Lexington Books, 2017) (forthcoming).

35 Ernst M. Conradie, Reconciliation as a Guiding Vision for South Africa? Ed. Ernst M. Conradie (Stellenbosch: SUN Press, 2013).

36 Willis Jenkins, The future of Ethics: Sustainability, Social Justice and Religious creativity (Washington: Georgetown University Press, 2013:139).

37 Dietrich Bonhoeffer, 'Ethics,' Dietrich Bonhoeffer Works 5. (Minneapolis: Fortress Press, 2005).

38 Ernst M. Conradie, "The Earth in God's Economy: Creation, Salvation and Consum $\neg$ mation in Eco $\neg$ logical Perspective." Studies in Religion and the Environment 10 (2012):59-106.

39 This formulation is derived from a draft proposal for a Sibylla Merian International Centre for Advanced Studies in the Humanities and the Social Sciences in Sub-Saharan Africa under the rubric of "Entangled Sustainabilities". I was indicated as a co-researcher in the proposal and thus had access to documentation that is no longer in the public domain. The proposal was in the end unsuccessful but the concept of "entangled sustainabilities" remains in my opinion attractive.

40 Ernst. M Conradie. Redeeming Sin? Social Diagnostics Amidst Ecological Destruction (Lanham: Lexington Books, 2017) (forthcoming).

41 Pearson, Clive. Oceaning Readings on Creation and Redemption. Creation and Salvation, Volume 2: A Companion on Recent Theological Movements. Studies in Religion and the Environment. ed. Conradie, Ernst M. Vol. 6. (Berlin: LIT Verlag, 2012).

42 Herman Bavinck, "Common Grace" (translated by R.C. van Leeuwen). Calvin Theological Journal 24 (1989):35-65.

Murray H. Coetzee, and Ernst M. Conradie. "Apartheid as Quasi-Soteriology: The Remaining Lure and Threat." Journal of Theology for Southern Africa 138 (2010):112-23.

43 Murray H. Coetzee, and Ernst M. Conradie. "Apartheid as Quasi-Soteriology: The Remaining Lure and Threat." Journal of Theology for Southern Africa 138 (2010):112-23.

44 Susan E. Schreiner, "Creation and Providence." The Calvin Handbook. Ed. Selderhuis, Herman J. (Grand Rapids: WB Eerdmans, 2009).

45 Charles M. Wood, Vision and Discernment: An Orientation in Theological Study. Atlanta: Scholars Press, 1985

46 Heiko Oberman, The Two Reformations: The Journey from the Last Days to the New World. (New Haven: Yale University Press, 2003):69.

47 See the essay by Jaap Durand on the "finger of God" in his Teks binne Konteks: Versamelde Opstelle oor Kerk en Politiek, edited by DJ Smit (Bellville: Universiteit van Wes-Kaapland, 1987):91-99.

48 John Russell, Nancey Murphy, and William R. Stoeger. Scientific Perspectives on Divine Action: Twenty Years of Challenge and Progress. (Vatican City: Vatican Observatory Publications, 2008). 
See also Ernst M. Conradie, Lewend En Kragtig? In Gesprek Oor God Se Handelinge. (Wellington: Bible Media, 2010).

49 Austen Farrer, Faith and Speculation. (London: Adam \& Charles Back, 1967).

50 John R Lucas. Freedom and Grace. Grand (Rapids: Eerdmans, 1976).

Brümmer, Vincent, "Farrer, Wiles and the Causal Joint." In: Brümmer on Meaning and the Christian Faith (Aldershot Ashgate, 2007):283-294.

Reichard, Joshua. "Pentecost, Process, and Power: A Critical Comparison of Concursus in Operational Pentecostal-Charismatic Theology and Philosophical Process-Relational Theology." University of the Western Cape (2010).

51 Willis Jenkins, The Future of Ethics: Sustainability, Social Justice, and Religious Creativity. (Washington: Georgetown University Press, 2013).

52 Ernst M. Conradie, “An Emerging Horizon: Learning to See the World in a Different Light through the Liturgy." The Nature of Things: Rediscovering the Spiritual in God's Creation. eds. Bruxton, Graham and Norman Habel. (Eugene: Pickwick, 2016) 41-57.

53 As a 'systematic' theologian I offer a nod of appreciation here in the direction of the biblical scholar in Professor Hendrik Bosman who is honoured in this volume of essays. I trust that he will forgive any shallow or distorted exegesis on my part. I would think that the notion of 'olam' would readily prompt him to raise a glass of good red wine as a gift from God amidst his labours (Eccl 3:11-13).

54 Willis Jenkins, The Future of Ethics: Sustainability, Social Justice and Religious creativity (Washington: Georgetown University Press, 2013:42).

55 Holmes (III) Rolston, Conserving Natural Value. New York Columbia University Press, (1994). 